HoLmes, F. O. (1955). J. gen. Microbiol. 12, 356-357

\title{
The Classification of Viruses
}

\author{
BY F. O. HOLMES \\ The Rockefeller Institute for Medical Research, New York City, U.S.A.
}

Several revisions and discussions of viral nomenclature have been published in the last few years. In $1953 \mathrm{~V}$. M. Zhdanov proposed a complete set of Linnaean binomials for viruses causing diseases in higher animals and insects (Opredelitel' Virusov Celoveka $i$ Zhivotnych, published by the Academy of Medical Sciences of the U.S.S.R., Moscow, 348 pages). In the same year, V.L. Ryshkov presented an even more extensive system of Linnaean binomials, attempting to show interrelationships between viruses that cause diseases of animals and those that cause diseases of plants (Sowjetwissenschaft, Naturw. $A b t ., 6,151)$. Both of these authors supported the contention that binomial nomenclature is appropriate for viruses. The same opinion was expressed in 1954 by N. O. Frandsen who reviewed in a thorough and unbiased manner all earlier proposals for viral nomenclature. Frandsen stated that the principle of nomenclature that is chosen ought not to reflect particular systematic concepts of viruses. Instead it ought to provide for the greatest possible continuity of naming, as our knowledge of viral relationships changes and grows with the passage of time. He indicated further that binomial nomenclature is especially well adapted to provide continuity for naming when there is progressive improvement in our knowledge. He felt that Fawcett misinterpreted the nature of binomial nomenclature when he claimed to have combined the advantages of the Johnson-Smith numbering principle with those of binomial nomenclature. Fawcett's 1940 proposal involved dual names of which the first member included the name of the host plant genus in which the virus originally was discovered. Frandsen believed that Thornberry's proposal in 1941 also is not to be regarded as involving the principle of binomial nomenclature, even though it contemplates dual names, because his use of a single genus Phytovirus for all phytopathogenic viruses reduces his proposal in reality to a method involving a single rather than a dual designation. Frandsen pointed out that one implication in the use of the principle of binomial nomenclature for phytopathogenic viruses is that variation among viruses centres around a taxonomic unit of a rank that is comparable to that of species among animals and plants. He noted wide recognition of the fact that this implication is essentially justified for viruses, and that it often finds expression in the literature by designation of the entities as species. Moreover, he felt that many investigators have admitted that the experience of the last decade has substantiated the further assumption of a possibility of natural groupings of viruses at a higher level, that of the genus. Frandsen observed that certain groups of viruses having a community of characteristics, but differing more or less among themselves, have come to be recognized. 
He concluded that the principal advantage of binomial nomenclature consists in the fact that changes in the surroundings of systematic units can be undertaken according to rules that ensure a comprehensive stability and unity to names. There is the added advantage that each investigator who wants to undertake such changes will be forced to show the precise reason for his proposed changes as opposed to existing conceptions.

\section{REFERENCES}

FAwCETT, H. S. (1940). Suggestions on plant virus nomenclature as exemplified by names for citrus viruses. Science, $92,559$.

Frandsen, N. O. (1954). Das Nomenklaturproblem der phytopathogenen Viren. Z. Pflkrankh. 61, 241.

Thornberry, H. H. (1941). A proposed system of virus nomenclature and classification. Phytopathology, 31, 23. 